Ян То,

аспірант Харківської державної академії культури

ORCID 0000-0002-2292-9406

\title{
ІСТОРИЧНИЙ ГЕНЕЗИС ТА ПЕРШИЙ ПЕРІОД ФОРМУВАННЯ КИТАЙСЬКОЇ ФОРТЕПІАННОЇ СОНАТИ
}

Мета роботи - визначення історичного генезису та розвитку фортепіанної сонати впродовж найпершого періоду її становлення. Методологія дослідження полягає в застосуванні історико-генетичного, історикоконтекстуального, історико-аналітичного методів дослідження. Наукова новизна роботи обумовлена встановленням історичного генезису китайської фортепіанної сонати упродовж 1915 - 1939 рр. Визначено низку жанрів (п'єса, прелюдія, фуга, сюїта, китайська художня пісня, китайська фортепіанна художня пісня), в яких відбилися фрагменти національного звукового образу фортепіано, що віднайде цілісне втілення в китайській фортепіанній сонаті; підкреслено значення розвитку виконавської піаністичної культури, що сприяв утворенню жанру китайської фортепіанної культури. Виявлено значення першого фортепіанно-сонатного періоду розвитку жанру національної музичної культури. Упродовж 10-річчя - з 1939 по 1949 рр. (дата народження КРН) у китайських фортепіанних сонатах, що збереглися, сформовано характерні образні світи святковий та ліричний, апробовано внутрішньожанрові різновиди - «маленьку сонату» (іiі перші взірці створені Чжан Ван $€$ і Ло Чжуньжунь) та програмну сонату, опрацьовано основи сонатного формотворення. Висновки. Китайська фортепіанна соната постає як узагальнення широкого кола інновацій у національній музичній культурі, що відбувалися впродовж 1915 - кінця 1940-х років.

Ключові слова: китайська фортепіанна соната, «китайське фортепіано», китайський звуковий образ фортепіано, китайська фортепіанна художня пісня, пісня без слів.

Ян То, аспирант Харьковской государственной академии культуры

Исторический генезис и первый период формирования китайской фортепианной сонаты

Цель работы - определить сущность исторического генезиса и развития фортепианной сонаты на протяжении первого периода ее становления. Методология исследования основана на применении историко-генетического, историко-контекстуального, историко-аналитического методов исследования. Научная новизна работы обусловлена установлением исторического генезиса китайской фортепианной сонаты в течение 1915 - 1939 гг. и значения первого фортепианно-сонатного периода с 1939 по 1949 гг. (дата рождения КНР). Установлены жанры (пьєса, прелюдия, фуга, сюита, китайская художественная песня, китайская фортепианная художнеественная песня), в которых были сформированы фрагменты национального звукового образу фортепиано, что обретут целостное воплощение в китайской фортепианной сонате; подчеркнуто значение развития исполнительской пианистической культуры, способствовавшей образованию жанра китайской фортепианной сонаты. Доказано, что в китайских фортепианных сонатах первого периода развития были сформированы характерные для жанра образные миры - праздничный и лирический, апробированы внутрижанровые разновидности - «маленькая» и программная соната, отработаны основы сонатного формообразования. Выводы. Китайская фортепианная соната трактована как обобщение широкого круга инноваций в национальной музыкальной культуре втечение 1915 - конца 1940-х годов.

Ключевые слова: китайская фортепианная соната, «китайское фортепиано», китайский звуковой образ фортепиано, китайская фортепианная художественная песня, песня без слов.

Yang Tuo, postgraduate student of the Kharkiv State Academy of Culture, Kharkiv

Historical genesis and the earliest formation period of the chinese piano sonatas

The purpose of the article is to define the historical genesis and development of a piano sonata during the earliest period of its formation. The methodology involves applying the historical and genetic, historical, and contextual, historical, and analytical methods of research. The scientific novelty is conditioned by determining the historical genesis of Chinese piano sonatas during 1915-1939. The author specifies the number of genres (play, prelude, fugue, suite, Chinese art song, Chinese piano song), in which the fragments of the national sound picture of the piano were made that would find a coherent embodiment in the Chinese piano sonata. The author emphasizes the importance of the development of performing pianist culture, which contributed to the formation of the genre of Chinese piano culture. The author describes the value of the first piano and sonata period in the development of the genre of the national music culture. During the decade - from 1939 to 1949 (the date of birth of the People's Republic of China) in Chinese piano sonatas that were preserved, the characteristic metaphoric worlds were formed - festive and lyrical, intrinsic genre varieties were tried out - "little sonata" (Zhang Wang Ye and Lo Zhunrun created its first pieces) and descriptive sonata, the essentials of the sonata formation were perfected. Conclusions. The Chinese Piano Sonata has a well-developed historical genesis within the national musical culture. The genesis of the Chinese Piano Sonata concerns

(С) То, 2019 
genres whose formation preceded its emergence. Among them are piano miniatures (march, polyphonic genres prelude, fugue), suite (one of which is written in the genre of Tokai), Chinese art song, Chinese piano art song. During the pre-sonata phase, such "worlds" as lyrical and festive, characteristic of the Chinese Piano Sonata, were formed, which would continue to be of significant importance in the development of the genre that is the subject of study in this work. During the years 1915 - 1939, fragments of the castle image of the piano were composed, which in the Chinese Piano Sonata would find its holistic embodiment. In addition to composer creativity, the birth of the genre of Chinese piano sonata is due to the development of the pianistic performing culture. The value of the first piano-sonata period of genre development in Chinese musical culture is hard to overestimate. During the 10th anniversary of the birth of the People's Republic of China in 1949, the five surviving Chinese Piano Sonatas formed the genre of its own. This is the so-called "little sonata" (Zhang Wang Ye and Lo Zhunzhun created its first designs), which has continued to evolve throughout the 90-year history of the genre. Summarizing the processes of formation of sound of "Chinese piano" as a prerequisite for the first period of development of the national Chinese sonata, it should be noted that the genre under study appears as a generalization of a wide range of innovations in Chinese musical culture, which took place during the early 1940 s - late 1940 s

Key words: Chinese piano sonata, "Chinese piano," Chinese piano sound picture, Chinese piano art song, a song without words.

Актуальність теми дослідження. Історія розвитку китайської фортепіанної сонати обумовлена політичними, загальнокультурними й суто мистецькими подіями розвитку країни. У вивченні китайської фортепіанної сонати в музичній науці Піднебесної значне місце належить історичному підходу, що сприяє розробці періодизації історії жанру та систематизації його жанрових різновидів. Однак у китайському музикознавстві й досі не існує послідовного дослідження щодо вивчення найпершого періоду в історії розвитку жанру фортепіанної сонати. Пов’язаний із десятиліттям (з 1939-го до 1948-го року), що безпосередньо передує утворенню у 1949 року КНР, цей період має історико-художнє значення для формування китайської фортепіанної сонати. У цей 10-річний період виникли п'ять перших китайських фортепіанних сонат, 3 якими пов'язане народження національного різновиду жанру. Оскільки китайські дослідники розпочинають вивчення історії китайської фортепіанної сонати 3 утворення КНР, поза межами їхньої уваги залишалися взірці жанру, що були написані до цієї дати. Історія розвитку жанру скорочується на десятиліття, а кількість періодів його розвитку зменшується. Невизначеним залишається й питання щодо історичного генезису китайської фортепіанної сонати, сутність якого полягає не тільки у констатації значення європейського прообразу, але й у розгляді жанрових прообразів та художніх процесів, що обумовили його перетворення на стійкий жанр у музичній культурі Китаю. Отже, актуальними завданнями музикознавства постають вивчення специфіки історичного генезису китайської фортепіанної сонати; дослідження найранішого етапу розвитку китайської фортепіанної сонати з метою формування об'єктивного підходу до усвідомлення розвитку жанру з історичних позицій. Мету дослідження обумовлює визначення історичного генезису та розвитку фортепіанної сонати упродовж найпершого періоду іï становлення.

Аналіз останніх досліджень і публікацій. Відомості щодо розвитку фортепіанної сонати упродовж десятиліття 1939 - 1948 містяться переважно в довідниках і мають фактологічний характер. Будь-які наукові праці, які б містили спроби аналітичного освоєння відповідних взірців, відсутні. Отже, на теперішній час у Китаї не існує спеціального дослідження, в якому б послідовно й систематично було опрацьовано інформацію, пов'язану з генезисом і розкриттям специфіки жанру китайської фортепіанної сонати впродовж першого 10-ліття її існування.

Виклад основного матеріалу дослідження. Фортепіанна соната в контексті національного мистецтва постає як один із зовнішніх музичних жанрів за своїм походженням (як, скажімо, китайська художня пісня, поліфонічні жанри, взірці симфонічної та оперної музики європейського походження). Прийшовши до Китаю ззовні національної культури (з західно-європейської музики), пройшовши стадію «націоналізації» (насичення ознаками національної ментальності, стилістики, мелодичного мислення), китайська фортепіанна соната поступово набула ознак нащіонального жанру.

Процес перетворення фортепіанної сонати з жанру, що прийшов до китайської культури ззовні, на жанр іманентно їй властивий, був достатньо розгорнутим і багатовимірним. Йому передують десятиліття передісторії, жанрово-стильового генезису, коли низка взаємообумовлених історико-художніх процесів та жанрів європейського походження сприяли набуттю фортепіанною сонатою статусу національного.

Передісторією розвитку китайської фортепіанної сонати виступає «китайська фортепіанна освіта» [4]. Китайські церковні школи (першою 3 них була Шанхайська школа для дівчат «Санта-Марія», відкрита 1903 року) стали першими закладами, де навчалися грі на фортепіано на основі західної музичної культури. Поступове формування «базової моделі шкільної музичної освіти» [там само], поширеної на всю країну, привело до професіоналізації фортепіанної освіти як основи музичнопедагогічної діяльності. Першим наслідком цього процесу стало відкриття Музичної академиї Сиску, 
Пекінської педагогічної школи, заснованої 1912 року. Тепер уже не лише священники, але й китайські музиканти, що повернулися на батьківщину після навчання за кордоном, а також іноземні вчителі навчали дітей грі на інструменті. Серед перших учителів гри на фортепіано, які сприяли розвитку китайської піаністичної освіти - італійці Маріо Пачі $(1878$ - 1946) та учень Ф. Ліста Джованні Сгамбаті (1841 - 1914). На початку 1920 рр. класи фортепіано відкривалися в багатьох «нормальних школах» (наприклад, у Пекінській жіночій нормальноі школі музичні класи були створені 1922 року), а до структури університетів запроваджувалися музичні факультети та інститути (Музичний інститут Пекінського університету було засновано 1924 року). Національну консерваторію була відкрито у Шанхаї 1927 року; у липні 1929 року іï було перетворено на Національну музичну академію, директором якої став Сяо Юмея. Саме тоді розпочалася «... історія підготовки професіональних піаністів Китаю на засадах західного фортепіанного мистецтва.

Ознакою генетичного процесу формування китайської фортепіанної сонати постає розвиток національної піаністичної культури. 3 другої половини 1910-х - по кінець 1930-х років було сформовано професійне національне фортепіанне виконавство. Коли Сяо Юмей залучив до викладання учня Анни Єсипової Бориса Захарова (1888 - 1943) та польского піаніста Леопольда Годовського (1870-1983), настала нова епоха в історії національного фортепіанного мистецтва. Саме тоді розпочалось формування традиції китайського фортепіанного виконавства, представниками якого стали учні Б. Захарова Лі Цуйвей, Дін Шанде, Чжан Ивей, Йі Кайдзі, Фань Цзісень, У Леці.

Фортепіанне виконавство поступово перетворювалося із запозиченого, позакитайського на національний вид мистецтва. Наприклад, Хуан Цзи, що навчався фортепіанного виконавства поза межами Китаю, долучився до виховання першого покоління піаністів, що зростало вже на національній основі. До перших композиторів-піаністів, що здобули професійну освіту в Китаї, належать, зокрема, Хе Лютинг (1903 - 1999) і Лю Шу Ан (1905 - 1999).

Від 1910-х років до 1948 року, коли, завдяки зусиллям китайських музикантів, що набули професійної освіти в Європі та США (підкреслимо в цьому зв'язку роль Хуан Цзи), відкривалися національні музичні навчальні заклади різного рангу, було пройдено шлях щодо надання фортепіано, як музичному інструменту, що символізував виключно західну художню культуру, функції втілення національного звукового символу світу (народження звукового образу «китайського фортепіано»). Його формуванню сприяв розвиток низки жанрів, різною мірою пов'язаних із фортепіано.

Як і в Свропі, виникнення китайської фортепіанної сонати значною мірою обумовлено розвитком національної фортепіанної мініатюри.

Історичний генезис китайської фортепіанної сонати, перш за все, слід пов'язати з попередніми національними тембровими аналогами в інших жанрах. Найранішим історичним взірцем китайської музики для фортепіано є «March of Реасе» - мініатюра, створена Чжао Ю Жен 1915 року. Саме до цього твору йде генезис не тільки китайської фортепіанної сонати, але й багатьох інших жанрів національної фортепіанної музики. Восьмитактовий марш у «китайському стилі» вирізняе контрастування фрагментів, базованих на ознаках ангемітонності (пентатоніки - як мажорної, так і мінорної; як у мелодичному, так і в гармонічному видах), і таких, яким властиві елементи хроматизації. Формування початкового й завершального фрагментів на пентатонічних основах надає ангеметоніці «первинного» значення у «китайському марші».

«Китайський марш миру» Чжао Ю Жен - перший фортепіанний твір в історії національної фортепіанної культури в жанрі мініатюри - постає як один із тих інструментальних жанрів, що властивий як європейській, так і китайській музичній цивілізації. Підкреслимо, що впровадження жанрових ознак маршу до сфери сонатного тематизму надалі постає як характерна ознака китайської фортепіанної сонати.

Значну роль у формуванні цілісного звукообразу «китайського фортепіано», відтвореного в жанрі сонати, відіграли сольні фортепіанні твори різних жанрів, що виникли впродовж 1930-х років. Вони безпосередньо передували появі першої національної китайської сонати 1939 року.

Насамперед відзначимо поліфонічні твори Хуан Цзи, написані композитором-піаністом у першій половині 1930-х років за європейськими прелюдійними та фугованими взірцями. Здобувши освіту в Німеччині і США, Хуан Цзи надав перші взірці поліфонічного тлумачення «китайського фортепіано». Завдяки досвіду Хуан Цзи до китайської фортепіанної сонати ввійшли поліфонічні розділи, зокрема, до розробки, створеної (як і в багатьох європейських взірцях) за поліфонічним принципом розвитку тематизму.

Засвоєння жанрових ознак фортепіанної сюїти як циклічного жанру в передсонатний період розвитку китайської музичної культури значною мірою сприяло формуванню китайської фортепіанної сонати. Сюїта в китайській музичній культурі постає як той циклічний жанр, що безпосередньо вплинув 
на появу перших національних фортепіанних сонат. Чотири століття поспіль у Китаї спостерігалася художня ситуація, значною мірою подібна до тієї, що характеризувала народження сонати «з духу сюїти» в Європі XVII століття. Серед китайських фортепіанних сюїт, що передували появі першої національної сонати для фортепіано, значне місце належить чотрирьохчастинному зразку жанру, написаному Лю Шу Ан 1936 року. Лю Шу Ан (випускник Шанхайської консерваторії, вчителем якого був Хуан Цзи) створив фортепіанну сюїту програмного типу: кожна її частина має програмну назву (1 ч. «Перше вечірнє свято», II ч. - «Лялька, що танцює», III ч. - «Дивитися зверху вдалечінь», IV ч. ). У китайській сюїті було сформовано передумови деяких внутрішньожанрових різновидів китайської фортепіанної сонати. Серед таких, по-перше, програмна соната i, по-друге, «маленька соната». Актуальні для перших періодів розвитку китайської фортепіанної сонати іiї програмний i «малий» різновиди зберегли своє значення і на початку XXI століття.

У сюїті Лю Шу Ан було закладено й один з характерних образних станів, що набув розвитку в китайській фортепіанній музиці впродовж усіх періодів іiі розвитку. Це образ свята, що в контексті китайської фортепіанної сонати має значення стабільної змістової характеристики.

У китайському сюїтному циклі, що на кшталт класичного європейського прообразу також має чотири частини, своєрідно відтворено характерний темповий контраст: дві перші частини написані у швидких темпах (I ч. - Allegro; II ч. - Allegro vivace), третю частину тлумачено як повільний центр (Andante cantabile), четверта пов'язана із поверненням швидкого темпу (Allegretto con brio). Зазначимо, що наявність темпового контрасту у китайській сюїті не означає точного наслідування темпових ознак європейського прообразу. Якщо класичні взірці європейської сюїти формуються на основі парного зіставлення повільних і швидких частин із поступовим нарощуванням темпового контрасту, то Лю Шу Ан базує сюїтний цикл на іншій темповій закономірності. Нарощуючи швидкість темпу від I до II частини, композитор надає лише одну повільну частину (замість двох у класичній сюїті), повертаючись до чергової градації швидкого темпу в останній частині. Водночас у відповідності до європейського класичного прообразу повільний центр сюїтного циклу композитор пов'язує саме 3 III частиною. Внаслідок розміщення повільного центру в III частині в китайській сонаті зберігається властивий європейському прообразу темповий контраст між III (повільною) i IV (швидкою) частинами. Загалом темпова невідповідність китайської сонати європейській моделі фокусується лише між I і II частинами, організованими за принципом «швидко і ще швидше».

Якщо європейська класична сюїта базується на контрасті старовинних танців, то в сюїті китайській танець як такий представлений лише в єдиній (II) частині, що має програмну назву «Лялька, що танцює». Однак акцент на жанрових моделях властивий й іншим частинам сюїтного циклу, що також вказує на зв'язки з європейським прообразом. Наприклад, I частина написана в жанрі токати, що сприяє розкриттю функції фортепіано як «ударного» інструмента; III - має ознаки ліричної пісні для фортепіано, IV вогняного танцю.

Враховуючи значущість вокальної культури Китаю, в генетичному процесі формування національної китайської сонати слід виокремити жанр китайської художньої пісні, що походить від німецької Kunstliede [Юань, Цао Хе]. Китайська художня пісня до появи національної фортепіанної сонати пройшла два етапи розвитку - 1920 роки (представлена, зокрема, у творчості Цін Чжу, Чжао Юань Женя) і 1930 роки (мистецтво Хуан Цзи, Чень Тянь Хе). У ній фортепіанна партія розкривала психологічний підтекст образного світу ліричного героя, досягала високої виразності й технічної складності. Від китайської художньої пісні фортепіанна соната успадкувала такі характерні жанровостильові риси, як виразність вокальної за своєю природою мелодії та ліричний тип вислову, притаманний повільним частинам сонатного циклу.

На формування звукообразу китайського фортепіано, що багатогранно відобразився у фортепіанній сонаті, вплинув жанр китайської фортепіанної художньої пісні (китайської художньої пісні для фортепіано). У ній утілились ознаки цілої низки жанрів європейського походження, що згодом набули значення національних у системі китайської музичної культури. До жанрових прообразів китайської фортепіанної художньої пісні слід віднести китайську художню пісню як таку (сформовану під впливом німецької Kunstliede), а також такі жанри європейської музичної культури, як мендельсонівський винахід - «пісня без слів», від початку призначена для виконання на фортепіано, а також фортепіанна обробка народної пісні. Зразки жанру китайської фортепіанної художньої пісні, що передували народженню фортепіанної сонати в музичній культурі Китаю, створені Лао Чжи Чен і Хе Лютинг. Китайська фортепіанна художня пісня «Дитячі веселощі» Лао Чжи Чен, створена 1932 року, написана в складній двохчастинній формі (1 ч. - Moderato, 2 ч. - Allegretto). Властива китайській фортепіанній пісні поліепізодна структура сприяє розкриттю ії програмного задуму, втілення якого потребувало постійної зміни тематичного матеріалу. Особливістю музичної драматургії фортепіанної 
пісні постає принцип чергування фрагментів скерцозного та ліричного характеру, що відображає мінливий характер дитячих ігор.

Китайські фортепіанні художні пісні Хе Лютинга, написані 1934 року («Колискова») і 1935 р. («Вечірнє свято»), відтворюють два найхарактерніші смислообрази китайської фортепіанної сонати ліричний і святковий. Народжений 1903 року, Хе Лютинг являє собою те перше покоління національних композиторів, яке здобувало професійну музичну освіту в Китаї (Шанхайська консерваторія) під керівництвом Хуан Цзи. Трьохчастинна «Колискова» - визнаний шедевр національного фортепіанного мистецтва - цілком основана на мелосі вокального походження, що лише зрідка виходить за межі мажорної пентатоніки. У китайській фортепіанній художній пісні «Вечірнє свято» відтворено властивий майбутній сонаті для фортепіано святковий образний світ.

На відміну від мендельсонівських «пісень без слів», китайська художня фортепіанна пісня масштабніша, має концертний характер, містить ознаки віртуозності.

Композитори «до-сонатного» періоду в історії китайської фортепіанної культури провіщали майбутні шляхи розвитку жанру сонати в контексті національної культури. Виникненню перших взірців фортепіанної сонати упродовж 1939 - 1949 років сприяв процес формування звукообразу китайського фортепіано в таких жанрах, як фортепіанна мініатюра, поліфонічні п’єси (прелюдії, фуги), сюїта як взірець циклічного жанру, китайська художня пісня, китайська фортепіанна художня пісня.

Значення перших зразків фортепіанної сонати, що виникли в китайській музичній культурі упродовж першого історичного періоду ії розвитку - упродовж десятиліття від 1939 до 1949 року, важко переоцінити. Адже саме тоді розпочався той величний шлях розвитку національного жанру, що нині нараховує 90 років. У сонатах першого періоду розвитку відбувся необхідний процес суміщення формотворчих і жанрових ознак європейської сонати й вираження національної ментальності.

Протягом першого 10-літнього періоду розвитку китайської фортепіанної сонати було написано п'ять зразків жанру. Автором найпершої китайської фортепіанної сонати, створеної 1939 року, став Ма Сi Цон. Наступного року (1940) Чжан Вен $€$ написав другу сонату в історії розвитку жанру (ор. 31). То була перша «Маленька фортепіанна соната» в історії розвитку жанру. Друга фортепіанна соната Чжан Вен $€$, на жаль, не збереглася: втрата ранніх зразків жанру - загальна проблема розвитку китайської фортепіанної культури першої половини XX століття. Третя фортепіанна соната Чжан Вен $\mathcal{C}$ (збережена) була створена 1945 року. 1946 року до написання китайської фортепіанної сонати (в E-dur) долучився Дін Шан Де, який і в наступні періоди розвитку жанру звертався до нього. 1947 року Ло Чжуньжунь написав I фортепіанну сонату, що стала останнім твором, що репрезентує I період у розвитку жанру. Композитор звернувся до найпоширенішого в майбутньому різновиду жанру, а саме «маленької сонати», який уперше створив Ма Сі Цон.

У трьохчастинній «маленькій сонаті» Ло Чжуньчжунь відтворений класичний для європейської жанрової традиції принцип чергування темпів Швидко - Повільно - Швидко (I ч. - Allegro scherzando, II ч. - Andantino, III ч. - Presto) за умов мінімізації контрасту поміж швидкими і центральною помірною частинами. Показовою $є$ відтворення в 1 частині, в якій домінують скерцозні образи, мініатюрної сонатної форми з домінуванням експозиційності над розробковістю (розробка базована на розвитку теми головної партії) та достатньо виразно представленою сонатною двотемністю. II частину вирізняє образний контраст між споглядальністю I-ого і ІІІ-ього розділів, що оточують драматичний центральний епізод із «хвильовим» розвитком інтонаційного матеріалу. Мініатюрною сонатною формою постає і III частина «маленької сонати». Ї̈і своєрідними ознаками щодо тематизму та формотворення постає застосування прийому «la melodia marcato» у викладі теми головної партії, побудова розробки на розвиткові та подрібненні теми побічної партії, уведення до репризи фрагментів, основаних на контрапунктичному розвитку обох тем, що чергуються з проведеннями теми головної партії.

Висновки. Китайська фортепіанна соната має достатньо розвинутий історичний генезис у межах національної музичної культури. Генезису китайської фортепіанної сонати стосуються жанри, формування яких передувало ії виникненню. Серед них - фортепіанні мініатюри (марш, поліфонічні жанри - прелюдія, фуга), сюїта (одна 3 частин якої написана в жанрі токати); китайська художня пісня; китайська фортепіанна художня пісня. Упродовж «до-сонатного» етапу сформувалися такі властиві китайській фортепіанній сонаті образні «світи», як ліричний і святковий, що будуть мати подалі значення основних у розвитку жанру, що постає предметом дослідження в цій роботі. Протягом 1915 - 1939 років було складено фрагменти того замкового образу фортепіано, що в китайській фортепіанній сонаті віднайде своє цілісне втілення.

Крім композиторської творчості, народження жанру китайської фортепіанної сонати обумовлено й розвитком виконавської піаністичної культури.

Значення першого фортепіанно-сонатного періоду розвитку жанру в китайській музичній 
культури важко переоцінити. Упродовж 10-річчя, до народження КНР 1949 року, в тих п’яти китайських фортепіанних сонатах, що збереглися, було сформовано властивий цьому жанру різновид. Це так звана «маленька соната» (iї перші зразки створені Чжан Ван $€$ і Ло Чжуньжунь), що продовжувала розвиватися протягом усієї 90-річної історії жанру.

Підсумовуючи розглянуті процеси формування звукообразу «китайського фортепіано» як передумови першого періоду розвитку національної китайської сонати, слід зазначити: жанр, що вивчається, постає як узагальнення широкого кола інновацій у китайській музичній культурі, що відбувалися упродовж початку 1920-х - кінця 1940-х років.

\section{Jimepamypa}

1. У Хун Юань. Китайська художня пісня: історія і теорія жанру : автореф. дис. ... канд. мистецтвознавства : спец. 17.00.03 «Муз. мистецтво» / Харків. нац. ун-т мистецтв ім. І. П. Котляревського. Харків, 2016. 24 с.

2. Чень Менмен. Чень Менмен. Релігійно-філософська концепція пісні Хуан Цзи «Закони неба». Культура Украӥни. Серія: Мистецтвознавство : зб. наук. пр. / Харків. держ. акад. культури. Харків, 2018. Вип. 59. C. $101-110$.

3. Чень Менмен. Специфіка взаємодії змісту і форми у вокальній мініатюрі Хуан Цзи на вірші Лью Сиан «Йдучи снігом». Культура України. Серія: Мистецтвознавство : зб. наук. пр. / Харків. держ. акад. культури. Харків, 2018. Вип. 61. С. 233-241.

4.王安潮.中国早期钢琴教育的史学研究 [ J ] . 晥西学院学报, 2009, ( 1 ) : 148 . (4. Ван Анчао. Історичне дослідження ранньої китайської фортепіанної освіти [J]. Журнал Західного університету Аньхой, 2009, (1): 148.)

5.下萌．中国钢琴文化之形成与发展 [ M ] . 华乐出版社，1996．26- 27，41，82-85. (5 Мо Бянь. Становление и развитие китайской фортепианной культуры [М]. Издательство Хуале, 1996.26-27, 41, 82-85.)

\section{References}

1. U Khun Yuan. Kytaiska khudozhnia pisnia: istoriia i teoriia zhanru : avtoref. dys. ... kand. mystetstvoznavstva : spets. 17.00.03 «Muz. mystetstvo»/ Kharkiv. nats. un-t mystetstv im. I. P. Kotliarevskoho. Kharkiv, 2016. p. 24. [in Ukrainian].

2. Chen Menmen. Chen Menmen. Relihiino-filosofska kontseptsiia pisni Khuan Tszy «Zakony neba». Kultura Ukrainy. Seriia: Mystetstvoznavstvo : zb. nauk. pr. / Kharkiv. derzh. akad. kultury. Kharkiv, 2018. Vyp. 59. pp. 101110. [in Ukrainian].

3. Chen Menmen. Spetsyfika vzaiemodii zmistu i formy u vokalnii miniatiuri Khuan Tszy na virshi Liu Syan «Iduchy snihom». Kultura Ukrainy. Seriia: Mystetstvoznavstvo : zb. nauk. pr. / Kharkiv. derzh. akad. kultury. Kharkiv, 2018. Vyp. 61. pp. 233-241. [in Ukrainian].

4. 王安潮．中国早期钢琴教育的史学研究 [ J ] . 皖西学院学报, 2009, ( 1 ) : 148. [in Chinese]. (4. Van Anchao. Istorychne doslidzhennia rannoi kytaiskoi fortepiannoi osvity [J]. Zhurnal Zakhidnoho universytetu Ankhoi, 2009, (1): 148. [in Chinese].

5. 六萌.中国钢琴文化之形成与发展 [ M ] . 华乐出版社, 1996 . 26- 27，41，82-85. (5 Mo Bian. Stanovlenye y razvytye kytaiskoi fortepyannoi kulturb [M]. Yzdatelstvo Khuale, 1996.26-27, 41, 82-85.)

Стаття надійшла до редакиії 30.10.2019 р. 